John Carroll University

Carroll Collected

Summer 2018

\title{
On the Popularity of the Kriminalroman: The Reception, Production, and Consumption of German Crime and Detective Novels (1919-1933)
}

Julia Karolle-Berg

John Carroll University, jkarolle@jcu.edu

Follow this and additional works at: https://collected.jcu.edu/fac_bib_2018

Part of the German Language and Literature Commons

\section{Recommended Citation}

Karolle-Berg, Julia, "On the Popularity of the Kriminalroman: The Reception, Production, and Consumption of German Crime and Detective Novels (1919-1933)" (2018). 2018 Faculty Bibliography. 66.

https://collected.jcu.edu/fac_bib_2018/66 


\section{On the Popularity of the Kriminalroman: The Reception, Production, and Consumption of German Crime and Detective Novels (1919-1933)}

In 1938, Bertolt Brecht opened his now-famous essay "Über die Popularität des Kriminalromans" with the assertion that "der Kriminalroman [trägt] alle Merkmale eines blühenden Literaturzweiges zur Schau" (504). ${ }^{1} \mathrm{He}$ was not alone in this opinion; throughout the 1920s and 1930s, authors, critics, and criminologists had weighed in on the rise and persistence of the genre. In a 1921 article in the Neue Zürcher Zeitung, Ferdinand Hardekopf expressed what would become a prevailing sentiment: "Es besteht keinerlei Aussicht darauf, daß [der Kriminalroman] verschwinde: zu tief nistet der Hang zum Aufregenden in den Nerven der Menschheit" (1). In 1930, Hanns Martin Elster confirmed that for the last few years, the current age had once again displayed "die Mode des Kriminal- und Detektivromans in Publikum und Literatur" (34; see Mayer 35). Indeed, Brecht's metaphor of the flourishing literary branch presumed an established form of popular literature, and his essay focused on the themes and schemata common to it.

Though Brecht and other cultural observers, such as Walter Benjamin and Siegfried Kracauer, recognized the significance of the genre in the 1920s and 1930s, the factors determining and defining its popularity during this period have largely remained outside the sight lines of postwar literary scholarship. In the 1980s, Knut Hickethier was among the first to interpret the rise in critical engagement with the Kriminalroman during the 1920s as an indicator of the form's ubiquity (15; see also Marsch 49), and other literary historians have since returned to essays by Brecht, Kracauer, or, somewhat less frequently, Benjamin (Herzog 13-33; Kniesche 2122). Yet it has been only relatively recently that researchers have furnished more specific details of the production of Kriminalromane in the German-speaking world during the 1920s and 1930s (Schädel), and to date, analyses of this period remain limited. To offer one example, the 2016 volume Crime Fiction in German: Der Krimi devotes only a few paragraphs to the Weimar-era Kriminalroman, despite "evidence of considerable German-language crime production in this period" (Hall 6). It is an irony of German literary history that so little remains known about the Kriminalroman of the 1920s and 1930s other than that it was wildly popular.

The era of the Weimar Republic - the years between the declaration of a democratic, parliamentary republic in 1919 and the inauguration of Adolf Hitler as 
chancellor, in 1933-thus invites closer study. ${ }^{2}$ One of the likely reasons for past scholarly neglect relates to the fact that popularity was long equated with triviality, casting discussions of Kriminalromane almost exclusively in terms of the highliterature / low-literature opposition that has been part of literary criticism in the German-speaking world since the Enlightenment (Hügel 344-45; Ladenthin 402). In this dichotomy, works perceived as popular had no intrinsic value, and were even seen as dangerous. Since the eighteenth century, increases in the production of popular literary forms often ignited debates on the cultural perils of Schund, Kitsch, and Trivialität (Hügel 345; Schulte-Sasse 138). With its rise at the turn of the twentieth century, the Kriminalroman was included among the regular targets of censure (Karolle-Berg 439-40). Even after 1945, the specter of popularity loomed large over scholarship on crime and detective fiction, precluding serious engagement with the genre as literature (Wörtche 344; Kniesche 11). As I have demonstrated elsewhere, the discourse on high versus low literature undeniably shaped perceptions of crime and detective fiction in the Germanspeaking world (Karolle-Berg 438-42). Building on my previous work, I propose an approach here that recognizes this discourse yet shifts the focus to contemporary reception, production, and consumption as indicators of the Kriminalroman's popularity. Even as Weimar-era sources acknowledge the persistent stigma of crime and detective fiction, they also document a complex, multivalent understanding of its popularity as the bourgeoisie increasingly participated in writing, reading, and commenting on the genre. During this period, essays on crime and detective fiction-which had long been absent from literary criticism — began to appear in newspapers, magazines, and other print sources, representing the first attempts at writing the Kriminalroman's literary history. Equally striking was the more frequent treatment of crime and detective fiction in book reviews by supraregional, bourgeois newspapers such as the Frankfurter Zeitung in the 1920s and 1930s. Assumptions about who wrote Kriminalromane during the Weimar era likewise demand revision in light of publishing practices that appear to have encouraged more German-language writers to produce crime novels. Ironicallyor fittingly, given that respected bourgeois authors may not have desired such popularity - the publishing model for establishing brand recognition worked against making individual authors popular. Finally, though popular literature has long been assumed to be the reading material of a "low-brow" audience (Hügel 345; Cuddon 729), evidence points to the existence of a bourgeois readership of Kriminalromane during the Weimar era. Yet precisely the status of the genre as a popular form excluded it from contemporary efforts to collect data on reader demographics and preferred authors. By exploring how the popularity of the Kriminalroman was thus constructed and obscured during this period, this study situates the genre within its particular cultural and social context to an extent that has been largely absent from scholarship to date. 


\section{The Discourse on the Kriminalroman as a Genre (1919-1933)}

Scholars of crime and detective fiction in the Anglo-American world describe the mid-1920s as the moment when the first concentration of writings on the genre qua genre emerged (Symons 104; Wölcken 11). In the German-speaking world, the increasing popularity of the Kriminalroman likewise catalyzed a broader-based and more serious engagement. Between 1919 and 1933, approximately twenty-five essays specifically thematizing the Kriminal- or Detektivroman as a literary genre appeared in newspapers, literary magazines, library journals, and collected volumes. One striking difference between the Anglo-American and German contexts is that while Anglo-American authors of crime and detective fiction began writing about the genre after World War I (Wölcken 12), their German-language counterparts did not participate as visibly in public discussions. Instead, it was cultural critics, editors, librarians, educators, and authors of other genres who tended to weigh in.

Edgar Marsch's 1983 study provides a brief overview of German-language criticism of crime and detective fiction (49-52), and Peter Nusser integrates a handful of early German-language contributions into the international discourse on the genre's history, poetics, and sociological and didactic implications (12-18). These contributions notwithstanding, for many years after 1945 a sentiment dominated the discourse that there was little favorable German-language literary engagement with crime and detective novels, then or since. Volker Ladenthin commented in 1985 that "alle lesen Krimis, aber niemand spricht über sie, kaum jemand rezensiert sie" (402), and Nusser opined in 2009, "die Beurteilung des Kriminalromans durch die Literaturkritik steht - jedenfalls in Deutschland - im Gegensatz zu seiner Popularität" (9). These observations reflect long-standing assumptions, but a more thorough investigation into literary discussions on the Kriminalroman poses a challenge to the presumed ubiquity of such sentiments.

Of the writers who dealt with the Kriminalroman during the Weimar era, Walter Benjamin, Bertolt Brecht, and Siegfried Kracauer are among the most recognizable today, and they have, by far, received the most attention among recent literary historians of the German-speaking world (Herzog 13-33; Lorenz Jäger; Kniesche 21-22; Wörtche 344-45). These authors' enduring prominence has, understandably, led scholars to grant their essays on the Kriminalroman pride of place. Yet lesser-known critics also wrote on the genre significantly earlier than Brecht did, and they attempted more-focused descriptions of crime and detective stories from a literary perspective than Benjamin, in his brief essay "Kriminalromane, auf Reisen" (1930), or Kracauer, in his ponderous "Ein philosophisches Traktat über den Detektiv-Roman" (1925). Indeed, the primary goal of these frequently cited essays by Brecht, Benjamin, and Kracauer is to explain the cultural appeal of Kriminalromane in modern society (Herzog 25), not to reconstruct the origins of the genre or to articulate its narrative devices or distinctions from other genres, even though some observations on such topics occur along the way. Rather than the iceberg itself, essays by Brecht, Benjamin, and Kracauer are merely the 
tip, suggesting a more significant critical engagement with the Kriminalroman during this period; still requiring exploration are the essays "under water"-that is, those written by critics now lesser known.

Like Brecht, Benjamin, and Kracauer, other cultural critics reflected on the social and cultural circumstances that gave rise to the Kriminalroman, but voices contributing to this discourse also focused on identifying origins, generic features, and new developments. Notable progenitors, such as Edgar Allan Poe, Émile Gaboriau, and Arthur Conan Doyle, were folded into a literary evolution that dated back to the mid-nineteenth century and that in the 1920s was yielding to other British, French, and Scandinavian authors. Such essays also often address notable developments in the genre during this period. In a perceptive article from 1918, Albert Ludwig points to a furcation in the lineage of the detective after Conan Doyle between everyday sorts of investigators (such as Balduin Groller's Onkel Dagobert) and those who border on the superhuman (such as Paul Rosenhayn's Joe Jenkins). The rise of Hochstapler, Gauner, and gentlemen thieves as protagonists was another recurrent theme (Ludwig 200-01; Mayer 33; Haas 5).

Less-known Weimar-era writers also described emerging conventions of the genre with a degree of sophistication comparable to Brecht, Benjamin, or Kracauer. Ignatz Gentges observed in 1926 that common themes among detective novels were the mystification of the proximate and everyday, the surprises of technological advances, and the isolation of the individual (14-15). These observations bear some similarity to the sentiments Todd Herzog has identified in Walter Benjamin's writings-namely, that "detective novels convert the strangeness of the city into mystery, thus rendering it potentially knowable" (25). Perhaps the most notable recognition that technical aspects of the genre were being considered (at least somewhat) seriously was an entry on the "Kriminalnovelle, -roman" in the 1926 edition of the Reallexikon der deutschen Literaturgeschichte. Here, Hugo Beyer isolates constitutive components of the detective novel, including the use of investigative combination to interpret clues and to reconstruct events, and the occurrence of red herrings within a narrative, which still had to maintain a sense of reasonable probability (144). These analyses anticipate Brecht's interpretation of reading a crime novel as akin to an exercise in applying the scientific method (506). Though it appeared in a rather unconventional and decidedly non-literary context, Paul Englisch's entry in the 1930 edition of the Handwörterbuch der Kriminologie provides rare insight into contemporary views of the genre through an impressive compendium of crime- and detective-fiction conventions of the time, including devices featured in works by German-language authors.

Like Brecht, Benjamin, and Kracauer, other authors tried to account for the contemporary appeal of the Kriminalroman. In 1929, Walter Haas pinpointed several facets of the genre's popularity that Brecht reprised about a decade lateramong them that puzzles can be solved in Kriminalromanen that cannot be solved in real life, and that causes have effects and effects have causes (Haas 6; Brecht 509). Haas concludes that the genre provides a reassuring, metaphysically ordered 
universe in an era "des sinkenden Glaubens, der sinkenden Ordnung, des drohnenden Chaos, einer unsicheren, neu entstehenden Ordnung" (6), which, with its religiously cast notions of guilt and redemption, resists the more secular reading of the genre by Brecht, Benjamin, and Kracauer. Yet, as Herzog has noted, the way in which the latter critics drew on the popularity of the detective novel as a "basis for theorizing about the role of reason and causality in modernity" (15) bears similarities to how Haas attempted to understand the Kriminalroman in the particular cultural context of the Weimar Republic (see also Guggenheim; and Mann).

Reviews of Kriminalromane also became more commonplace in the 1920s and 1930s, including in highly respected, international newspapers such as the Frankfurter Zeitung. ${ }^{3}$ While one admittedly cannot speak of a sea change, the evidence does suggest a shifting editorial policy and a realization that it was both legitimate and desirable to review such works. Of the more than 180 works reviewed in Sammelrezensionen in the Frankfurter Zeitung in 1913, only one crime novel was included: Otto Soyka's 1911 Die Söhne der Macht (Kalkschmidt). Between 1918 and 1933, by contrast, the Frankfurter Zeitung reviewed over 50 crime novels, including more than 30 by German-language authors (see Woisetschläger).

Though more scholarly attention has been paid to Siegfried Kracauer's essay on detective fiction, "Ein philosophisches Traktat über den Detektiv-Roman," his reviews for the Frankfurter Zeitung offer a striking example of how contemporary attitudes toward the genre were evolving. At first, Kracauer tended to approach featured novels as cultural phenomena to analyze, not as books to review for a curious reading public. A review from 1925, for instance, opens with the observation that kitschy literature fulfills a two-fold pleasure: it provides both "ästhetisch stilgerechte Bekundungen der gelebte Leere" and shows "die Wirklichkeit wie in einem Zerrspiegel" ("Spannende Romane" 191). These cultural ruminations recall the language of his philosophical treatise and foreground a cerebral, culturally critical intentionality to reading that invariably plays down the content of the "kitschy" works in question (see Kracauer, "Traktat"107: "[Detektiv-Romane] halten dem Zivilisatorischen einen Zerrspiegel vor”). In a 1927 review of multiple books, the secondary role that the books played is even more pronounced. Here, too, Kracauer leads with a heady rumination on a phenomenon of modern culture. When he turns to a treatment of the works, Kracauer spoils the ending of one, indicating his assumption that readers would not actually seek out the book in question ("Neue Detektivromane" 83).

Kracauer's reviews after August 1927, by contrast, focus more on evaluating individual books for their own merits, instead of according to the criteria laid out in his earlier treatise. Indeed, Kracauer increasingly considered what authors did well (or less well) in light of generic expectations. Among those praised are G. K. Chesterton, for his use of wit and suspense ("Das Paradies der Diebe" 643; "Zwei Detektivbücher [1929]"105), Earl Derr Biggers, for his character development and invocation of local color ("Das Haus ohne Schlüssel" 653), and Robert Gore-Brown, for his innovative methodology ("Verdacht" 21). Throughout his reviews, Kracauer 
also notes changes in the genre, such as the obsolescence of Holmesian tricks in the current age ("[Sherlock Holmes]" 119; see also "Conan Doyle †" 275).

To be sure, some critics remained hard pressed to take crime novels seriously (Hermann; -ck), but, like Kracauer, others distinguished between good or bad Kriminalromane based on the works' fulfillment of generic expectations or moreglobal standards of literary quality (Hardekopf; Kellner; W.P.). Such examples emend previous assumptions that the popularity of the Kriminalroman precluded German-language critics from engaging with it. The evidence suggests instead that critics of the day were treating it as one would treat a new and popular literary genre as it was becoming established and the details of its literary history were being codified. In the following sections, I consider the popularity of the genre in terms of its production and consumption, trends that also notably occupied the attention of contemporary critics of the Kriminalroman.

\section{Domestic and International Kriminalromane in the German-Speaking World (1919-1933)}

Literary historians have demonstrated that the publication of new titles of crime and detective fiction in German increased during the 1920s and 1930s. This trend echoed international ones: in the United Kingdom, for instance, as many detective stories appeared in 1929 and 1930 "as in the preceding eight years" (Starrett 51). Accounting for works translated into German as well as short-format works with a fixed number of pages (usually thirty-two, sixty-four, or ninety-six), and original German-language Kriminalromane, Irmtraud Götz von Olenhusen counts 743 new titles published in the German-speaking world in 1920 alone. My focus here is on "long-format" Kriminalromane-works that were not published in series with a fixed number of pages. These texts were more comparable to the short novels coming out of the Anglo-American world during this period (Suerbaum 74) and-as I suggested above-were increasingly taken seriously in public discourse. According to Mirko Schädel's bibliography, about 34 original Germanlanguage long-format Krimis were published in 1920.

In the German-speaking world, translations captured a significant market share, and book reviews and essays consistently highlighted international authors. Names commonly cited included Edgar Wallace (1875-1932), G. K. Chesterton (1874-1936), Frank Heller (1886-1947), and Sven Elvestad (1884-1934). A brief treatment of Edgar Wallace offers an illustrative example of international authors' impact on the German-language market.

Of all the international authors of crime and detective fiction, Wallace was the most successful - and contentious. Over 50 of his novels appeared in German between 1925 and 1930, with the total number of German-language copies in print reaching 1.5 million by 1929 (Vogt-Praclik 106). In 1927, Wallace's Der Hexer (initially published in English, as The Gaunt Stranger, in 1925, and revised and reissued as The Ringer in 1926) appeared in German, first as a play and soon after in novel form. The latter alone achieved at least 45,000 copies in print 
(Vogt-Praclik 108). ${ }^{4}$ Particularly after 1925 , references to Wallace abounded in writings on crime fiction (Tucholsky 229; Mann 1). In the early 1930s, Kracauer favorably reviewed two of Wallace's novels and, later, wrote his obituary in the Frankfurter Zeitung ("Detektivromane"; "Edgar Wallace †"). Bertolt Brecht even proclaimed, in a short piece on kitsch, that "den großen Wallace laß ich mir doch nicht nehmen!" (“[Was halten Sie für 'Kitsch'?]” 227). While parody may not be the sincerest form of flattery, it attests to a broad-based familiarity with Wallace that cabaret artist Hans Reimann published a persiflage of Wallace's stories in 1929. Waltraud Woeller has gone so far as to intimate that Wallace's popularity in the German-speaking world has been more enduring than in his native England - after all, the Goldmann Verlag, a German publisher, awarded an Edgar Wallace Prize in the 1960s (175).

The fact that crime novels were broadly popular among German-speaking readers but primarily produced by British, Scandinavian, and French writers caused some consternation among contemporary critics. In 1917, Kasimir Edschmid responded to claims that low-quality books predominated by stating it was time to heed the call to cultivate the genre in German ("Hochstaplerbücher" 1). In 1924, Thomas Mayer noted one response to this call by the Robert Lutz publishing house, which had been releasing increasingly more works by German authors (33). Alongside (and often in tandem with) a hope for increased domestic production of Kriminalromane, critics expressed a desire for higher literary quality. The conservative cultural critic Karl Christian Bry, for one, offered novels by Albrecht Schaeffer and Leo Perutz as antidotes to the domination of the foreign Kriminalroman in the German-speaking world.

Sie [Schaeffer's and Perutz's works] sind ohne Einschränkung Kunstwerke, die indes geschult sind an der festen und geschlossenen Technik des Kriminalromans. [...] Hier liegt Neuland; und man wird nach Perutz und Schaeffer etwas vorsichtiger sein müssen mit billigen Vorwürfen gegen die "Ausländerei und Unmoral der Sensationsliteratur." (694)

The production of original German-language detective novels did, in fact, increase in the 1920s (Karolle-Berg 435), and several German-language authors seemed to enjoy a degree of popularity as well as the respect of contemporary critics. Those most frequently mentioned include the German Paul Rosenhayn (1877-1929) and the Austrian Otto Soyka (1882-1955). Soyka in particular was consistently praised by critics for his innovative and thoughtful approach to the genre. Edschmid commented in 1921, for example, that Soyka wrote "die einzigen hochwertigen Kriminalromane in Deutschland" ("Deutsche Erzählungsliteratur" 2). Other prolific-albeit less celebrated-authors of the period included Eufemia von Adlersfeld-Ballestrem, Ferdinand Runkel, Hans Hyan, and Ludwig Wohl.

Looking beyond this small group of prolific authors, a striking aspect of domestic production was the sheer number of writers contributing to it, some of whom only ever wrote a single crime novel (Karolle-Berg 436). This trend did not abate; as domestic production increased, between 1919 and 1933, a growing 
number of authors contributed to it (437). Thus, in order to understand the nature of the Kriminalroman during this period, it seems one should understand the causes of this phenomenon. Two factors in particular may help account for the large number of authors who experimented with the crime-novel genre: economic circumstances and contemporary publishing practices.

As Anton Kaes and others have documented, the early 1920s saw authors struggling to earn a living wage (38-39; see also Brohm 208-10). As a result, many were compelled to write in multiple capacities to supplement their incomes, sometimes simultaneously writing for magazines, journals, and even advertising agencies (Kaes 43-44). That some writers made forays into the Kriminalroman in the hopes of producing a potboiler did not go unnoticed by critics; Bry, for instance, suggested in 1923 that the prevailing economic circumstances were driving writers to the genre who had no particular aptitude for it (695; see also Gentges 14). This phenomenon might, in part, explain why the Robert Lutz Verlag reported in 1924 that it had received more than 500 manuscripts for Kriminalromane over the course of five years - of which it published only 24 (Mayer 32).

In addition to being an outward expression of the financial desperation of authors, the debuts of new contributors to the genre may have been supported by trends in German-language publishing. Thorsten Grieser has shown that in Germany, book production for most of the first third of the twentieth century featured significantly more individual titles than in countries such as the US, France, or Great Britain (18). Grieser estimates that first editions amounted to an impressive 60 percent or so of the market share, but he speculates that the production volume of any given edition was likely smaller in Germany than in these other countries $(18,16)$. In other words, German publishers might have been more inclined to satisfy consumer demand for new Kriminalromane by publishing more novels with smaller runs, whereas English publishers debuted fewer new titles but likely issued more copies of each.

The drive to bring new Kriminalromane to market or to publish established authors under sometimes foreign-sounding pen names may also have been tied to what contemporaries termed a "Novitätensucht" — an addiction to new releases (Brohm 280). Before World War I, profits from the first printing of a book did not typically generate enough revenue to offset an affordable retail price. Publishers thus relied on subsequent printings every few years to recoup losses and to subsidize further investment. As Bertold Brohm notes, however, the production model changed in the 1920s, such that on average, public interest in a novel only persisted for about three years. The production volume of first editions decreased in order to minimize risk, and the number of new titles increased to maintain the volume of trade (280). Market pressures may have thus motivated publishers to debut more new works, effectively encouraging more authors to dabble in the genre and contributing to the notably diffuse production model in the German-speaking world. An interesting side effect of this model is that it appears to have downplayed the author's identity in favor of other strategies to attract potential readers. 
The value of understanding these cultural and economic circumstances becomes apparent when considering a novel such as Ole Stefani's Der dritte Schuss (1926). By contextualing this work in light of the evidence provided above, what might otherwise have been perceived as an outlier appears more representative of the Kriminalromane of its day. Its author, Hans Schweikart (1895-1975), a German film and theater director and actor, wrote three novels explicitly advertised as Kriminalromane. Published pseudonymously, Der dritte Schuss was marketed as a translation from the Danish, though its foreign guise remained superficial: the plot takes place around Cologne. Thematically, Der dritte Schuss bears resemblance to Wallace's best-selling Hexer, published the year before in English. In both stories, a criminal has sworn revenge on the man responsible for his incarceration. Having escaped prison, the criminal insinuates himself into the man's circle of acquaintances and eventually succeeds in murdering him. Among the plot twists is the revelation that the criminal is not to be found among the suspicious strangers lurking here and there, but is instead a character known to the reader.

Like other artists of the time, Schweikart may have been supplementing his primary profession in film and theater by writing crime novels (see also Hickethier 16), and he or his publisher may have opted for a pseudonym in order to appeal to the public's taste for Scandinavian authors (see also Arnold 74). Despite the lack of name recognition, Schweikart/Stefani's first foray into the Kriminalroman earned the praise of some literary elites. Arthur Ernst Rutra commented in Die literarische Welt in 1927 that "über spannende Effekte hinaus,"Stefani mastered "eine bemerkenswerte Charakterzeichnung"(5). Kracauer likewise weighed in favorably ("Neue Detektivromane" 582).

At first blush, it seems surprising that an unknown author such as "Ole Stefani" should have been positively reviewed. Yet the fact that Der dritte Schuss was reviewed at all could well be attributed to the fact that it ran in a crime series by the respected publisher Georg Müller. Between 1926 and 1931, Müller released an impressive 45 novels in his series, and reviewers frequently conveyed their high expectations for subsequent releases. In 1927, Rutra observed what an honor it was for authors to be featured by Müller (5). A year later, Dora Sophie Kellner panned a handful of recent releases in the series, but more notable is her disappointment based on previous experience and expectations (8; see also Schäfer 123).

Crime-themed book series, such as the short-lived one by Müller, thus appear to have played a role in the distribution of Kriminalromane by serving as a mode of serialization and a tool for creating brand recognition. And there were many such series. At least 24 long-format crime-novel series other than Müller's ran for part or all of the Weimar era, several of which — such as Robert Lutz's Sammlung ausgewäblter Kriminal- und Detektivromane (Schädel 2:426-28) - had already existed well before 1919 . These series mixed translations with original German-language Kriminalromane, issuing on average four or five books a year. In the case of Georg Müller's series, 9 of the 45 novels included were by German-language authors. While one cannot deny the predominance of international 
authors in the crime-novel market, prominent book series may nevertheless provide a context in which to analyze how German-language authors co-constructed genre conventions in tandem with translated works.

Between 1919 and 1933, writing crime novels appears to have been a lucrative (and, thus, popular) secondary occupation for people otherwise involved in writing or the creative arts. Paradoxically, because readers favored novelty, publishers capitalized on the brand recognition of book series, making crime-novel writing a pursuit for which the authors themselves would likely not garner acclaim. These findings also point to possible reasons why Kriminalromane of this period, despite their significant domestic production, have remained difficult to characterize. Literary scholars after 1945 may not have considered the specific cultural and economic contexts in which Kriminalromane were produced, making it difficult to estimate their significance. By only looking for authors who produced many works in many editions, scholars may have overlooked the fact that much of German-language crime fiction consists of single works by a variety of authors. The consequences of this approach were that "the lack of individual, extraordinary cases in the German-speaking world akin to Arthur Conan Doyle's or Agatha Christie's stories meant that the only work to be done was to explain their absence" (Karolle-Berg 436). As I show in the next section, considering the Kriminalroman as a popular form existing within a particular economic, social, and cultural context is essential for understanding the genre's likely readers, as well as its authors.

\section{Popularity and the Challenge of Describing the Readership of Kriminalromane}

A common gambit in essays of the Weimar era was that even highly educated men read Kriminalromane. In 1920, Charlotte Bühler noted that the genre had found "viele ernsthafte Verfechter in gebildeten Kreisen" (183), and Hans Reimann quipped that "auch Bismarck verschlang Kriminalromane"(59; see also Mayer 32). In the 1920s and 1930s, Brecht, Benjamin, Kracauer, and Kurt Tucholsky unambiguously identified themselves as readers of the genre. To focus on only one example, Benjamin's reading list from 1917 to 1938 includes works by international crime-novel authors such as Georges Simenon, Agatha Christie, and Sven Elvestad, as well as German-language authors Paul Rosenhayn, Artur Landsberger, Artur Zapp, and Leo Perutz ("Verzeichnis" 437-76). In response to such revelations, publisher and literary scholar Hanns Martin Elster derided the phenomenon of educated people defending the genre (35).

As further testament that educated readers indulged in crime and detective fiction during this period, the respected literary journal Die literarische Welt published a serialized crime story in 1932, Die verschlossene Tür. Renowned crimenovel author Frank Arnau wrote the first and last chapters, and prominent writers such as Alfred Döblin and the court reporter Gabriele Tergit each contributed a chapter. As a Kriminalroman, Die verschlossene Tür was a spectacular failure (Arnold 82-85), and clearly a ploy to shore up journal readership during the slow 
months of the summer (Arnold 74). A reader contest associated with Die verschlossene Tür, which involved guessing the solution to the mystery, was only open to subscribers of Die literarische Welt.

The growing cultural visibility of the Kriminalroman in the 1920s and 1930s notwithstanding, identifying who was reading what authors remains a challenge. Anton Kaes has noted that this period produced a wealth of reader surveys (60), yet literature of a putatively higher caliber was more often their focus. To offer one example, in November 1922, as in previous years, the biweekly journal Das literarische Echo published the results of a survey of the most-requested books according to responses from "Stadtbüchereien und Lesehallen." After presenting his findings, the article's author, Hans Joachim Homann, admitted the following caveats:

Sie [the lists submitted from individual libraries] zählen ja nur auf, welche Bücher oder Autoren sich die Leserschaft aus den Beständen der Büchereien am liebsten aussucht. Eine Rundfrage bei allen erwachsenen Deutschen, vielleicht auch eine Rundfrage bei den dem Publikumsgeschmack fast ganz passiv gegenüberstehenden buchhändlerischen Leihbibliotheken würde ein ganz anderes Bild ergeben, sie würde möglicherweise zeigen, daß die Lieblingsautoren des deutschen Volks jetzt etwa Anny Wothe oder Helene [recte: Hedwig] Courths-Mahler wären, Autoren also, die in einer gut geleiteten Bücherei kaum vertreten sein dürften. (132)

These observations reprise a tension, frequently palpable during this period, between notions of "good literature" and the totality of people's reading habits. As Homann intimated, the well-run German public library had a mission to provide edifying works and to track their use; it was hardly to be expected that public libraries would even have Unterhaltungsliteratur on offer, let alone that they would monitor its circulation. Attitudes about popular literature as ephemeral likely contributed to contemporary resistance against documenting its readership; one of the most vociferous opponents of crime and detective fiction, Hanns Martin Elster, predicted in 1930 that Arthur Conan Doyle would eventually fall into obscurity and that Edgar Wallace would soon be recognized as boring (37). Why record the favor of authors whom later generations would not even know?

Despite the explicit resistence to documenting its trends, Homann's comments do point to the existence of popular literature, as well as to a common vehicle for accessing it: the Leibbibliothek. Privately owned, fee-driven lending libraries occupied a significant place in the cultural landscape of the first half of the twentieth century, particularly in hard economic times, such as the last years of the Weimar era (Georg Jäger 301). ${ }^{5}$ Information about reader preferences with respect to lending-library offerings remains anecdotal, yet it confirms the picture painted elsewhere. Kracauer reports in a 1931 essay, for instance, that the owner of a Berlin lending library observed an unusually strong taste for Kriminalromane among members of the intelligentsia ("Eine kleine Leihbibliothek" 132). A contemporaneous source from Vienna also noted the popularity of Kriminalromane among book borrowers there. Claiming holdings of 600,000 books, the Viennese 
Zentralbibliothek was the largest lending and public library in Europe during the early 1930s ("Das Haus der 600000 Bücher"), and appears to have followed a more inclusive approach to popular literature than German public libraries. A 1931 article summarizing circulation data from the 1920s reported that detective novels were the most popular type of book borrowed, even among doctors and lawyers (E. B-d). In 1933, the same library confirmed that the popularity of the genre was expanding, to the detriment of more "ambitious" literature ("Das Haus der 600000 Bücher"). Unfortunately, a comprehensive analysis of the holdings and lending trends among Leibbibliotheken during the Weimar era has yet to be undertaken. Alberto Martino's comprehensive history of German-language lending libraries from 1990 only provides data up to 1914. Georg Jäger, a contributor to Martino's study, points to the merits of pursuing such inquiry further: " $\mathrm{Da}$ Leihbibliotheken immer neue Ware anbieten mußten, heizten sie die 'Novitätensucht' an. An ihren Beständen lassen sich die Modewellen in der Unterhaltungsliteratur ablesen" (300). To the degree that it would be possible, a study of Weimar-era lending libraries could prove valuable to understanding the literary history of the German-language Kriminalroman.

Contemporary sources thus bear witness to a consensus that Kriminalromane claimed an increasing readership among the educated bourgeoisie; during the early 1900s, however, discussions on this topic were fraught with tensions and value judgments. Elster, for instance, equated the defense of the genre by educated elites with cultural decline and the eroding significance of Bildung, "ein Zeichen sinkenden Verantwortungsgefühls für den geistigen und seelischen Zustand des Gebildeten, ein Zeichen unseres Zurücksinkens in Kolonialverhältnisse" (38). While Elster feared that popular literature would crowd out high literature, defenders, such as Georg Schäfer, argued for the legitimacy of Gebrauchsliteratur as an appropriate medium to relax with after engaging mental work, while traveling, or before bedtime — as long as books met certain standards of quality (123). These clashing viewpoints indicate an awareness of the changing role of literature, and show how the genre of Kriminalliteratur may have served as a flash point for other social and cultural anxieties.

\section{Conclusion}

I have suggested here that in order to understand the popularity of the Kriminalroman during the 1920s and 1930s, it is essential to understand how the bourgeoisie participated in its reception, production, and consumption. Yet the Kriminalroman was not the only popular form on the rise. The 1920s saw the proliferation of entertainment options— several imported from the USA — including sports, film, music, and radio, all of which competed with books for market share and attention (Kaes 51-56; Raabe 31). The reimagining of cultural forms from autonomous entities to consumer products that fulfilled demands for "Information, Bildung, Unterhaltung oder Zerstreuung" resulted in what Kaes has termed a "Funktionswandel 
der Kultur" in the first years of the Weimar Republic (54; see also Füssel 435). This cultural shift was coupled with a decline in the economic and social influence of the bourgeoisie (Kaes 39; von Saldern 243), such that the bourgeoisie as standard bearers of taste and the book as a bourgeois status symbol appeared to many to be imperiled (von Saldern 213; Raabe 30). In 1926, reacting to the perceived decline in the status of the book and the public obsession with new releases, publisher Samuel Fischer went so far as to declare a "Bücherkrise" (Füssel 435-36). Fischer likewise mourned the decline of the bourgeois social sphere as a bastion of what was culturally good and right. As Fischer put it, before the end of the Wilhelmine Empire, this social class had spread "eine Atmosphäre von Kultur und Sitte [...] und all jene Elemente anzog, die in Gesellschaft, Wissenschaft und Kunst Ansehen und Einfluss gewonnen hatten" (qtd. in Füssel 436).

The popularity of the Kriminalroman in the German-speaking world has yet to be examined in the context of this "Funktionswandel der Kultur" in particular, though touch points are not difficult to find. Dime-novel versions of Kriminalromane were associated with cultural imperialism from America, for instance (Calmes 1077), and they were the particular target of censorship discussions in the Reichstag (Petersen 57). As these few examples suggest, the Kriminalroman could provide a rich case study of how discourses on the "popular" were being framed for and by the Bildungsbürgertum precisely at a moment that Adelheid von Saldern has called a "Beginn einer Globalisierung des kulturellen Massenwarenmarktes" (217). Admist the perceived loss of ground by intellectual elites in the creation and evaluation of German-language cultural products, it is not entirely surprising that the popularity of crime novels among the bourgeoisie prompted Elster to make subtle accusations of class treachery (38). In 1924, Karl Lerbs offered a more equanimous response to the popularity of the Kriminalroman.

Wenn ernsthafte Männer, denen es nicht nur ums Honorar zu tun ist, die ohne Zweifel auch anderes schaffen können, "die Detektivgeschichte pflegen," wenn ebenso ernsthafte Männer auf Vorhalten eingestehen, daß ihnen solche Geschichten zuweilen nicht unlieb zu lesen seien - so muß doch wohl etwas mehr dahinter stecken. (12, emphasis in original)

Lerbs's proposition humorously synthesizes aspects of the reception, production, and consumption of the Kriminalroman during the Weimar era and turns the tensions inherent in this popularity into a justification for further exploration. To use Lerbs's formulation, it has been my intention here to get at "what was behind" the popularity of the Weimar-era Kriminalroman - as an outgrowth of a particular cultural and social context, and of the tensions engendered by it.

\section{Notes}

${ }^{1}$ It has become common practice in the German-speaking world to use the term "Kriminalroman" to refer to both thrillers as well as whodunits and to reserve "Detek- 
tivroman" for whodunits only; a practice that I follow here. To reflect the generic breadth of the term "Kriminalroman," I translate it as "crime and detective novel."

${ }^{2}$ Most available data on publishing and readership relate to the German Empire. I will primarily direct my attention toward this country, though sources suggest the presence of a similar public discussion on crime novels in Austria and Switzerland. Where relevant, I include materials from the German-speaking areas of these countries as well.

${ }^{3}$ Howard Haycraft reported a similar increase in reviews in the Anglo-American literary world during the 1920s and 1930s. Haycraft indicates that in the Book Review Digest, for instance, "no more than a dozen were reviewed in 1914, a figure which had grown to 97 in 1925 and to 217 in 1939" (qtd. in Symons 123).

${ }^{4}$ Vogt-Praclik mentions two different numbers of copies in print for this text: 58,000 (107) and 45,000 (108).

${ }^{5}$ Georg Jäger estimates that between 10,000 and 18,000 lenders existed in Germany in 1932 (301).

\section{Works Cited}

Arnold, Arnim, ed. Epilogue. Die verschlossene Tür. Bouvier, 1984, pp. 69-90.

B-d, E. "Wien liest weniger als früher." Literaturblatt der Frankfurter Zeitung, vol. 64, no. 38, 20 Sept. 1931, p. 5.

Beyer, Hugo. "Kriminalnovelle, -roman.” Reallexikon der deutschen Literaturgeschichte, edited by Paul Merker and Wolfgang Stammler, vol. 2, de Gruyter, 1926, pp. 143-45.

Benjamin, Walter. "Verzeichnis der gelesenen Schriften." Gesammelte Schriften, edited by RolfTiedemann and Hermann Schweppenhäuser, vol 7.1, Suhrkamp, 1989, pp. 437-76.

--. "Kriminalromane, auf Reisen." Gesammelte Schriften, edited by Tillman Rexroth, vol. 4.1, Suhrkamp, 1972, pp. 381-83.

Brecht, Bertolt. "Über die Popularität des Kriminalromans.” Schriften 1933-1942, edited by Inge Gellert and Werner Hecht, vol. 2.1, Aufbau/Suhrkamp, 1993, pp. 504-10.

--. [“Was halten Sie für 'Kitsch'?"] Schriften 1914-1933, edited by Werner Hecht, vol. 1, Suhrkamp, 1992, pp. 227-28.

Brohm, Bertold. "Das Buch in der Krise. Studien zur Buchhandelsgeschichte der Weimarer Republik." Archiv für Geschichte des Buchwesens, edited by Monika Estermann and Reinhard Wittmann, vol. 51, Buchhändler-Vereinigung, 1999, pp. 189-329.

Bry, Karl Christian. "Verbrecherschwarten." Das literarische Echo, vol. 25, 1922/23, pp. 688-95.

Bühler, Charlotte. "Die Motivgruppen im Massenroman.” Die Hochwacht, vol. 9, no. 8, 1919/20, pp. 173-84.

Calmes, [Michael]. "Schund und Schmutz in ihren vielfachen Erscheinungsformen." Schönere Zukunft, vol. 3, no. 49, 1927/28, pp. 1076-78.

-ck. "Mosaik. Neue Romane." Frankfurter Zeitung, vol. 74, no. 478, 29 June 1929, p. 1.

Cuddon, John Anthony. "Popular Novel." A Dictionary of Literary Terms and Literary Theory, edited by Cuddon, 3rd ed., Basil Blackwood, 1991, p. 729.

Edschmid, Kasimir. "Deutsche Erzählungsliteratur." Frankfurter Zeitung, vol. 66, no. 546, 26 July 1921, pp. 1-2.

--. "Hochstaplerbücher. Eine Verteidigung des Kriminalromans." Frankfurter Zeitung, vol. 61, no. 4, erstes Morgenblatt, 5 Jan. 1917, p. 3.

Elster, Hanns Martin. “Der Kriminal- und Detektivroman.” Die Gegenwart, vol. 59, Feb. 1930, pp. 34-38. 
Englisch, Paul. “Der Kriminalroman.” Handwörterbuch der Kriminologie und der anderen strafrechtlichen Hilfswissenschaften, edited by Alexander Elster and Heinrich Lingemann, vol. 2, de Gruyter, 1930, pp. 1-10.

Füssel, Stephan. "Medienverbund statt Bücherkrise. Zum Verhältnis von Buch und Film in der Weimarer Republik." Buchkulturen. Beiträge zur Geschichte der Literaturvermittlung, edited by Monika Estermann, Ernst Fischer, and Ute Schneider. Harrassowitz, 2005, pp. 431-43.

Gentges, Ignaz. "Etwas über den Abenteuer-, Zukunfts-, Detektiv- und okkulte Romane.” Bücherwelt, vol. 23, no.1, 1926, pp. 14-17.

Götz von Olenhusen, Irmtraud. "Mord verjährt nicht. Krimis als historische Quelle (19001945)." Geschichte im Krimi. Beiträge aus der Kulturwissenschaften, edited by Barbara Korte and Sylvia Palatschek, Böhlau, 2009, pp. 105-28.

Grieser, Thorsten. "Buchhandel und Verlag in der Inflation. Studien zu wirtschaftlichen Entwicklungstendenzen des deutschen Buchhandels in der Inflation nach dem Ersten Weltkrieg." Archiv für Geschichte des Buchwesens, edited by Monika Estermann and Reinhard Wittmann, vol. 51, Buchhändler-Vereinigung, 1999, pp. 1-188.

Guggenheim, Ernst. “Das Geheimnis des Conan Doyle.” Rheinische Zeitung, vol. 192, no. 614, 1 Dec. 1929, n. pag.

Haas, Walter. "Ein paar Notizen über Wallace und die Kriminalliteratur überhaupt." Die literarische Welt, vol. 5, no. 26, 1929, pp. 5-6.

Hall, Katharina. "Crime Fiction in German: Concepts, Developments and Trends." Crime Fiction in German: Der Krimi, edited by Hall, Cardiff UP, 2016, pp. 1-32.

Hardekopf, Ferdinand. "Kriminalgeschichte." Neue Zürcher Zeitung, vol. 173, 3 Feb. 21, p. 1.

"Das Haus der 600000 Bücher. Was die Wiener lesen." Neue Freie Presse, no. 24589, 25 Feb. 1933, p. 5.

Hermann, Max. Rev. of Der Schatten der Suzette, by Walter Harich. Frankfurter Zeitung, vol. 751 , no. 41, 7 Oct. 1928 , p. 6.

Herzog, Todd. Crime Stories: Criminalistic Fantasy and the Culture of Crisis in Weimar Germany. Berghahn, 2009.

Hickethier, Knut. "Der Alte Deutsche Kriminalroman. Von vergessenen Traditionen.” Die Horen, vol. 31, no. 4, 1986, pp. 15-23.

Homann, Hans Joachim. "Die meistgelesenen Bücher. Nach einer Anfrage an Volksbüchereien." Das literarische Echo, vol. 25, no. 3, 1 Nov. 1922, pp. 129-35.

Hügel, Hans-Otto. “Populär.” Handbuch Populäre Kultur, edited by Hügel, Metzler, 2003, pp. 342-48.

Jäger, Georg. "Leihbibliothek." Handbuch Populäre Kultur, edited by Hans-Otto Hügel, Metzler, 2003, pp. 299-301.

Jäger, Lorenz. "Mord im Fahrstuhlschacht. Benjamin, Brecht und der Kriminalroman.” The Other Brecht II/Der andere Brecht II, edited by Marc Silberman, Anthony Tatlow, Renate Voris, and Carl Weber, Brecht Yearbook / Das Brecht Jahrbuch, vol. 18, 1993, pp. 25-40.

Kaes, Anton. "Schreiben und Lesen in der Weimarer Republik." Literatur der Weimarer Republik, 1918-1933, edited by Bernhard Weyergraf, Hanser, 1995, pp. 38-64.

Kalkschmidt, Eugen. "Neue deutsche Erzählungsliteratur." Frankfurter Zeitung, vol. 57, 26 Feb. 1913, p. 1.

Karolle-Berg, Julia. “The Case of the Missing Literary Tradition: Reassessing Four Assumptions of Crime and Detective Novels in the German-Speaking World (19001933)." Monatshefte für deutschsprachige Literatur und Kultur, vol. 107, no. 3, 2015, pp. 431-54. 
Kellner, Dora Sophie. "Neue Kriminalromane." Die literarische Welt, vol. 4, no. 47, 1928, p. 8.

Kniesche, Thomas. Einfübrung in den Kriminalroman. Wissenschaftliche Buchgesellschaft, 2015.

Kracauer, Siegfried. “Conan Doyle †.” 1930. Essays, Feuilletons, Rezensionen, edited by Inka Mülder-Brach, vol. 3. Suhrkamp, 2011, pp. 274-75.

--. "Detektivromane." 1931. Essays, Feuilletons, Rezensionen, vol. 3, pp. 687-88.

--. "Edgar Wallace †."1932. Essays, Feuilletons, Rezensionen, vol. 4, pp. 37-39.

--. "Einige Detektivromane."1925. Essays, Feuilletons, Rezensionen, vol. 2, pp. 319-22.

--. "Das Haus ohne Schlüssel.” 1927. Essays, Feuilletons, Rezensionen, vol. 2, pp. 652-53.

--. "Eine kleine Leihbibliothek." 1931. Essays, Feuilletons, Rezensionen, vol. 3, pp. 615-20.

--. "Neue Detektivromane." 1927. Essays, Feuilletons, Rezensionen, vol. 2, pp. 580-85.

--."Ein philosophisches Traktat über den Detektiv-Roman." 1925. Werke, edited by Inka Mülder-Brach and Ingrid Belke, vol. 1, Suhrkamp, 2006, pp. 105-209.

--. "Das Paradies der Diebe." 1927. Essays, Feuilletons, Rezensionen, vol. 2, pp. 642-43.

--. "[Sherlock Holmes].” 1929. Essays, Feuilletons, Rezensionen, vol. 3, p. 119.

--. "Spannende Romane." 1925. Essays, Feuilletons, Rezensionen, vol. 2, pp. 191-95.

--."Verdacht." 1928. Essays, Feuilletons, Rezensionen, vol. 3, p. 21.

--. "Zwei Detektivbücher." 1929. Essays, Feuilletons, Rezensionen, vol. 3, p. 105.

Ladenthin, Volker. "Das Rätsel des deutschen Kriminalromans.” Deutsche Criminalgeschichten von Schiller, Goethe, Kleist, E.T.A. Hoffmann und anderen, edited by Ladenthin, Insel, 1985, pp. 401-22.

Lerbs, Karl. Introduction. Der Griff aus dem Dunkel. Detektivgeschichten zeitgenössischer Erzähler, edited by Lerbs, Singer, 1924, pp. 7-20.

Ludwig, Albert. "Der Detektiv." Das literarische Echo, vol. 21, no. 4, 1918, pp. 193-203.

Mann, Heinrich. “Detektiv-Romane.” Die literarische Welt, vol. 5, no. 34, 23 Aug. 1929, pp. 1-2.

Martino, Alberto. Die deutsche Leibbibliothek. Geschichte einer literarischen Institution (17561914). Harrassowitz, 1990.

Marsch, Edgar. Die Kriminalerzäblung. Theorie, Geschichte, Analyse. 2nd ed., Winkler, 1983.

Mayer, Theodor Heinrich. “Detektivromane.” Neue Freie Presse, no. 21377, 16 Mar. 1924, pp. 32-34.

Nusser, Peter. Der Kriminalroman. 4th ed., Metzler, 2009.

P., W. Review of Der Ruf der Tiefe by Max Uebelhör. Frankfurter Zeitung, vol. 369, no. 20, 19. May 1929, p. 7.

Petersen, Klaus. Zensur in der Weimarer Republik. Metzler, 1995.

Raabe, Paul. "Das Buch in den zwanziger Jahren. Aspekte einer Forschungsaufgabe.” Das Buch in den zwanziger Jahren, edited by Paul Raabe and Ernst Hauswedell, 1978, pp. 9-32.

Reimann, Hans. Männer, die im Keller husten. Parodien auf Edgar Wallace. Steegemann, 1929.

Rutra, Arthur Ernst. "Die Kriminalromane des Georg-Müller-Verlags.” Die literarische Welt, vol. 3, no. 35, 1927, p. 5 .

Saldern, Adelheid von. "Überfremdungsängste. Gegen die Amerikanisierung der deutschen Kultur in den zwanziger Jahren." Amerikanisierung. Traum und Alptraum im Deutschland des 20. Jabrhunderts, edited by Alf Lüdke, Inge Marßolek, and Adelheid von Saldern, Franz Steiner, 1996, pp. 213-44.

Schädel, Mirko. Illustrierte Bibliographie der Kriminalliteratur im deutschen Sprachraum von 1796 bis 1945.2 vols., Achilla, 2006.

Schäfer, Georg. “Kriminalromane.” Die Bücherwelt, vol. 26, no. 2, 1929, pp. 122-24.

Schulte-Sasse, Jochen. Kritik an der Trivialliteratur seit der Aufklärung. Fink, 1971. 
Sta[rrett], V[incent]. "Mystery Stories." Encyclopedia Britannica, 1946, pp. 49A-51.

Stefani, Ole [Hans Schweikart]. Der dritte Schuss. Georg Müller, 1926.

Suerbaum, Ulrich. Krimi. Eine Analyse der Gattung. Reclam, 1984.

Symons, Julian. Bloody Murder: From the Detective Story to the Crime Novel. 1972, rev. ed., Mysterious Press, 1992.

Tucholsky, Kurt. "Kriminalromane." 1928. Gesammelte Werke, edited by Mary GeroldTucholsky and Fritz Raddatz, vol. 6, Rowohlt, 1975, pp. 229-30.

Vogt-Praclik, Kornelia. Bestseller in der Weimarer Republik (1925-1930). Traugott Bautz, 1987.

Wallace, Edgar, Der Hexer. Goldmann, 1927.

Wölcken, Fritz. Der literarische Mord. Eine Untersuchung über die englische und amerikanische Detektivliteratur. Nest, 1953.

Woeller, Waltraud. Illustrierte Geschichte der Kriminalliteratur. Insel, 1984.

Wörtche, Thomas. "Kriminalroman." Reallexikon der deutschen Literaturwissenschaft, vol. 2, de Gruyter, 2000, pp. 342-45.

Woisetschläger, Karl. "Die Rezeption neuer Erzählliteratur in der Neuen Freien Presse und der Frankfurter Zeitung 1918-33.” Dissertation, University of Vienna, 1991. 